\title{
ANALYZING SYSTEM-CONTROLLED COMMUNICATION AUTOMATIC DRILLING WELLS
}

\section{АНАЛІЗ ЗВ'ЯЗКІВ КЕРУВАЛЬНИХ ДІЙ У СИСТЕМІ АВТОМАТИЧНОГО УПРАВЛІННЯ БУРІННЯМ СВЕРДЛОВИН}

\author{
Vitaliya B. Kropyvnytska \\ vitalia.krop@gmail.com \\ ORCID: 0000-0001-5231-7104
}

\author{
В. Б. Кропивницька,
}

канд. техн. наук, доцент

\author{
Ivano-Frankivsk National Technical University of Oil and Gas, Ivano-Frankivsk \\ Івано-Франківський національний технічний університет нафти і газу, м. Івано-Франківськ
}

\begin{abstract}
The paper considers peculiarities of wells drilling process for the tasks of automated control. The separation of the drilling equipment is made on seven subsets, which allowed to formalise the task of automated control of drilling process in the choice of a rational mode of operation of a particular well. It is shown that each flight the drill bit is characterized by a tuple of three vectors: performance indicators and vectors managing and perturbation actions. The problem of selecting the optimum axial force on the drill bit as the main control action at the drilling wells with diamond and roller-bit drills.

The method of choice of the basic values of axial force and rotational speed which corresponds to minimum specific energy consumption, which will reduce energy consumption of fuel and energy complex by reduction of power consumption on the process of hydrocarbon extraction is suggested.

It is geometrically shown that with increasing axial force on the drill bit frequency of its rotation decreases. This allows us to conclude that the need to introduce a mathematical model of the process of drilling equation, which binds the axial force on the drill bit with the frequency of its rotation.

The result of the study is a system of equations, which allows to obtain the basic values of the control process of deepening oil and gas wells, taking into account the restrictions on them. Selection of the drilling technique for a predetermined drill range is taken into account in constraints, which provides optimal mode of operation under specific physical and mechanical properties of rocks. In addition, an equation is obtained that allows to determine the connection between the axial force on the drill bit and the frequency of its rotation.

Obtained by the author results of the study may be used in automation of control and managing systems of drilling process of oil and gas wells by rotary method. The complexity of automatic control process of deep wells drilling is determined due to the large number of runtime combinations.
\end{abstract}

Key words: mathematical model; specific energy consumption; Intercommunication; steering; control system; drilling process.

Анотація. У статті розглянуто особливості моделювання процесу буріння свердловини для завдань автоматизованого управління. Зроблено поділ бурової техніки на сім підмножин, що дозволило формалізувати завдання автоматизованого управління процесом буріння під час вибору раціонального режиму експлуатації конкретної свердловини. Показано, що кожен рейс долота характеризується кортежем із трьох векторів: показників ефективності та векторів керувальних і збурювальних дій. Визначено складність завдання автоматизованого управління процесом буріння глибоких свердловин, зважаючи на велику множину комбінацій бурової техніки. Проаналізовано проблему вибору оптимального осьового зусилля на долото як основної керувальної дії під час буріння свердловин алмазними та шарошковими долотами.

Запропоновано метод вибору базових значень осьового зусилля і частоти обертання, яким відповідає мінімум питомих витрат енергії, що дозволить знизити енерговикористання паливно-енергетичного комплексу шляхом зменшення витрат енергії на процес видобування вуглеводнів.

Геометрично показано, що зі збільшенням осьового зусилля на долото частота його обертання зменшується. Це дозволяє зробити висновок про необхідність введення в математичну модель процесу буріння рівняння, яке зв'язує осьове зусилля на долото із частотою його обертання.

Результатом дослідження є система рівнянь, яка дозволяє отримати базові значення керувальних дій процесу поглиблення нафтових та газових свердловин з урахуванням обмежень на них. В обмеженнях неявно враховується вибір множини бурової техніки для заданого інтервалу буріння, що забезпечує оптимальний 
режим роботи за конкретних фізико-механічних властивостей гірських порід. Крім того, отримано рівняння, яке дозволяє визначити зв'язок між осьовим зусиллям на долото та частотою його обертання.

Отримані автором результати дослідження можуть бути використані в автоматизованій системі контролю й управління процесом буріння нафтових і газових свердловин роторним способом.

Ключові слова: математична модель; питомі витрати енергії; взаємозв’язки; керувальні дії; система управління; процес буріння.

\section{ПОСТАНОВКА ЗАДАЧІ}

Задача автоматизованого управління процесом буріння нафтових і газових свердловин, який $є$ нелінійним динамічним процесом, що розвивається в часі, $\epsilon$ невизначеною, оскільки в математичних моделях процесу буріння немає рівняння, яке б пов'язувало осьове навантаження на долото із частотою його обертання. Тому не завжди вдається точно описати i передбачити режим його функціонування. Задача ускладнюється тим, що для різних способів буріння ці моделі можуть бути різними, оскільки механічні характеристики приводів подачі й обертання долота суттєво відрізняються для кожного способу буріння. За таких обставин дослідження зв'язків керувальних дій у системі автоматизованого управління бурінням свердловин набуває особливої актуальності.

\section{АНАЛІЗ ОСТАННІХ ДОСЛІДЖЕНЬ І ПУБЛІКАЦІЙ}

Вагомий внесок у дослідження особливостей моделювання процесу буріння нафтових і газових свердловин зробили М.І. Горбійчук та Г.Н. Семенцов [1], О.Ю. Витязь, О.Т. Драганчук, В.І. Векерик [2], Е.І. Стетюха, А.А. Голев [3], М.А. Мислюк, Ю.О. Зарубін [4] та ін. Серед закордонних учених варто назвати Е.А. Козловського [5], В.А. Бражникова [6], М.М. Блізорукова, В.П. Прокоп'єва, Е.О. Сулла [7], А.К. Рахімова [8], Г.Д. Бревдо, Г.М. Бриля, В.І. Дмитрієва [9], Г.С. Оганова, С.А. Ширин-Заде, А.А. Парамова [10], S. Parepa [11], T.M. Warren [12], I.E. Eronimi, W.H. Samerton, D.M. Auslander [13], C.E. Aboujaoude [14], A.P. Christoforou [15] та ін. Однак ще бракує наукових праць, у яких комплексно розглядається питання зв'язків керувальних дій у системі управління процесом буріння нафтових і газових свердловин 3 погляду мінімуму питомих витрат енергії.

\section{МЕТА ДОСЛІДЖЕННЯ}

Метою статті $€$ аналіз зв'язків керувальних дій в автоматизованій системі управління бурінням свердловин, а також визначення їхніх базових значень, яким відповідає мінімум питомих витрат енергії на поглиблення свердловини.

\section{МЕТОДИ, ОБ'СКТ ТА ПРЕДМЕТ ДОСЛІДЖЕННЯ}

Об'єктом дослідження $є$ процес поглиблення нафтових і газових свердловин.

Предметом дослідження є математичні моделі процесу поглиблення нафтових і газових свердловин з погляду визначення оптимальних значень керувальних дій.

\section{ОСНОВНИЙ МАТЕРІАЛ}

Аналіз літературних джерел [1-15] показав, що множина бурової техніки, яка необхідна для буріння нафтових і газових свердловин, складається з таких підмножин

$A=\left\{a_{1}, a_{2}, a_{3}, \ldots, a_{i}\right\}$ - типи бурових установок;

$B=\left\{b_{1}, b_{2}, b_{3}, \ldots, b_{k}\right\}$ - типи бурильних труб;

$C=\left\{c_{1}, c_{2}, c_{3}, \ldots, c_{l}\right\}-$ типи обважених бурильних труб;

$D=\left\{d_{1}, d_{2}, d_{3}, \ldots, d_{m}\right\}-$ типи вибійних двигунів;

$E=\left\{e_{1}, e_{2}, e_{3}, \ldots, e_{n}\right\}-$ типи доліт;

$F=\left\{f_{1}, f_{2,} f_{3}, \ldots, f_{p}\right\}-$ електрообладнання;

$G=\left\{g_{1}, g_{2} g_{3}, \ldots, g_{r}\right\}$ - засоби контролю й управління.

Кожна множина $\{A, B, C, D, E, F, G\}$ задається своїми технічними характеристиками і ціною. Для буріння свердловини в будь-якому інтервалі глибин на будь-якому родовищі вуглеводнів може бути застосований будь-який з елементів множини наборів техніки. Проте, з урахуванням складності заміни деяких елементів обладнання, усю бурову техніку можна поділити на дві категорії:

I. Бурова техніка, яку обирають один раз на свердловину і не міняють у разі переходу від одного інтервалу глибин до іншого, $\epsilon$ множина $A$ типів бурових установок; множина $B$ типів бурильних труб; множина $F$ електрообладнання; $G$ - засоби контролю й управління.

II. Бурова техніка, яку можна замінити під час переходу від одного інтервалу до наступного. Сюди входять множини C, D, E.

З урахуванням цих категорій бурової техніки множину наборів техніки, з якої можна буде вибрати техніку для буріння будь-якої свердловини, можна визначити так:

$$
\begin{aligned}
& \left\{M_{1}\right\}=\left\{a_{1}, a_{2}, a_{3}, \ldots, a_{i}\right\} \cdot\left\{b_{1}, b_{2}, b_{3}, \ldots, b_{k}\right\} \times \\
& \quad \times\left\{f_{1}, f_{2}, f_{3}, \ldots, f_{p}\right\} \cdot\left\{g_{1}, g_{2}, g_{3}, \ldots, g_{r}\right\} .
\end{aligned}
$$

Множина наборів бурової техніки, яка міняється в разі переходу від одного інтервалу свердловин до наступного, визначається так:

$$
\begin{gathered}
\left\{M_{2}\right\}=\left\{c_{1}, c_{2,} c_{3}, \ldots, c_{l}\right\} \times \\
\times\left\{d_{1}, d_{2}, d_{3}, \ldots, d_{m}\right\} \cdot\left\{e_{1}, e_{2}, e_{3}, \ldots, e_{n}\right\} .
\end{gathered}
$$

Якщо врахувати кількість інтервалів $J$ однорідних порід, то множина наборів бурової техніки $\{M\}$, яку можна використовувати для буріння свердловини, становить:

$$
\{M\}=\left\{M_{1}\right\} \cdot\{M\}^{J}
$$




\section{АВТОМАТИЗАЦІЯ ТА КОМП'ЮТЕРНО-ІНТЕГРОВАНІ ТЕХНОЛОГІЇ №2ロ 2020}

Отже, множина бурової техніки, що використовується для буріння конкретної свердловини $\left\{M_{c}\right\}, \epsilon$ складовою частиною множини (3), тобто $\left\{M_{c}\right\} \in\{M\}$.

Така різноманітність комбінацій бурової техніки підкреслює складність задачі автоматизованого управління процесом буріння 3 метою забезпечення мінімальних витрат у конкретних геолого-технологічних умовах, коли треба забезпечити раціональний режим експлуатації множини $\left\{M_{c}\right\}$ бурової техніки впродовж кожного рейсу долота.

Упродовж рейсу долота реалізується три режими експлуатації множини бурової техніки $\left\{M_{c}\right\}$ :

- механічного буріння, режим якого задається сполученням осьового зусилля на долото $F(t)$, механічної частоти обертання долота $\omega_{b}(t)$ і витрати промивальної рідини $Q(t)$;

- спуско-підіймальні операції, режим яких задається швидкістю спуско-підйому $V_{d l o}$;

- промивання свердловини до і після завершення механічного буріння. Цей режим задається витратою промивальної рідини $Q$.

Оскільки зміна $Q$ пов'язана із залежністю втулок бурових насосів, на що потрібні певні витрати часу, промивання свердловини здійснюють із такою ж витратою, як і під час механічного буріння. Це дозволяє не розглядати режим промивання свердловини як самостійний і вважати, що $Q=$ const для заданого інтервалу і режиму буріння.

Отже, параметри режиму буріння $F(t), \omega_{b}(t), Q(t)$ $\epsilon$ компонентами вектора вхідних керувальних дій:

$$
Y_{i}(t)=Y\left[F_{i}(t), \omega_{b_{-} i}(t), Q_{i}(t)\right]
$$

на $i$-му рейсі долота, які забезпечують заданий режим експлуатації бурової техніки на цьому інтервалі.

Кожний набір бурової техніки $\left\{M_{c}\right\}$ у певних геолого-технічних умовах дозволяє реалізувати на $i$-му інтервалі деяку область режимів експлуатації (керу- вальних дій) $\left\{\bar{Y}_{i}(t)\right\}$, але в окремих випадках множина режимів може бути порожньою $\left\{\bar{Y}_{i}(t)=\varnothing\right\}$. Це означає, що існують такі набори техніки, які не дозволяють здійснювати процес буріння в заданих умовах.

Для того, щоб множина $\left\{\bar{Y}_{i}(t)\right\}$ не була порожньою, множина бурової техніки $\{M\}$ повинна задовольняти геологічним і технологічним обмеженням.

Зазначимо, що кожному вектору вхідних керувальних дій $Y_{i}(t) \in \overline{Y_{i}}(t)$ відповідає група показників ефективності закінченого рейсу долота: $h_{i}(t)$ - проходка на долото, $V p_{i}$ - рейсова швидкість буріння, $t_{d l o \_i}$ - час, що витрачений на спуско-підіймальні операції, $t_{n \_}-$час промивання свердловини, $C_{i}$ - собівартість метра проходки, $t_{d}$ - час буріння свердловини, технічний стан озброєння і опор долота $-\varepsilon(t), g(t)$.

Показники процесу буріння $є$ компонентами вектора $X_{i}(t)$ вихідних змінних:

$$
X_{i}(t)=X\left[h_{i}(t), V p_{i}, t_{d l o i}, t_{n i}, C_{i}, t_{d}, \varepsilon(t), g(t)\right] .
$$

Це дозволяє гіпотетичну модель процесу буріння свердловини подати у вигляді:

$$
X_{i}(t)=\varphi\left[Y_{i}(t)\right] .
$$

Отже, кожний рейс долота характеризується сукупністю керувальних дій $Y_{i}(t)$, показників ефективності $X_{i}$ $(t)$ і збурювальних дій $Z_{i}(t)$, які створюють кортеж:

$$
<Y_{i}(t), X_{i}(t), Z_{i}(t)>\text {. }
$$

Оскільки процес буріння як об'єкт керування $\epsilon$ нелінійним, стохастичним, невідтворюваним і таким, що розвивається в часі під впливом збурювальних дій, то модель (6) зазвичай розробляють на основі експериментальних даних. Такі моделі слушні лише для тих конкретних умов, за яких були отримані.

Загальна структура моделі процесу буріння свердловини як об'єкта керування типу МIMO [1] наведена на рис. 1 .

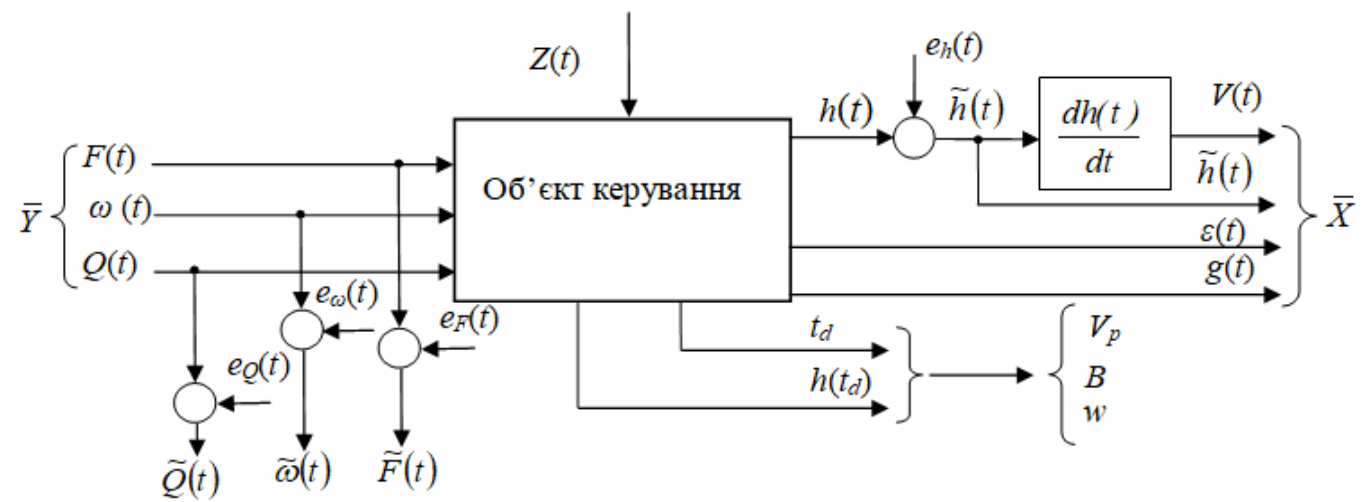

Рис. 1. Структура моделі процесу буріння свердловини як об'єкта керування: $\bar{Y}$ - вектор керувальних дій; $e_{Q}(t), e_{\omega}(t), e_{F}(t), e_{h}(t)$ - адитивні шуми вимірювальних каналів; $\bar{O}-$ вектор стану об'єкта керування; $\mathrm{w}$ - питомі витрати енергії 
Оскільки основною керувальною дією під час буріння свердловини алмазними і шарошковими долотами є осьове зусилля на долото $F(t)$, спочатку розглянемо основну проблему вибору оптимального осьового зусилля.

На керувальні дії і фазові координати накладені обмеження, суть яких випливає із фізичної сутності процесу буріння свердловин як об'єкта керування і процесів, що відбуваються в системі керування.

Проходка $h(0)$, знос опор $g(0)$ і оцінка відносного зносу озброєння долота $\varepsilon(0)$ на початку рейсу набувають таких значень [1]:

$$
H(0)=0 ; g(0)=0 ; \varepsilon(0)=1 \text { за } t=0
$$

а в кінці рейсу долота:

$$
h\left(t_{d}\right) \geq 0 ; 0 \leq g\left(t_{d}\right) \leq 1 ; 1 \leq \varepsilon(0) \leq(1+m)^{2} \text { за } t=t_{d},(9)
$$

де $m$ - коефіцієнт, що визначається геометрією зубців шарошки і формою зносу.

Технологічні обмеження

$$
\begin{gathered}
F(t) \in\left[F_{\text {max }}, F_{\text {min }}\right] \forall \mathrm{t} \in\left[t_{0}, t_{d}\right], \\
\omega_{b}(t) \in\left[\omega_{b_{-} \max }, \omega_{b_{-} \min }\right] \forall \mathrm{t} \in\left[t_{0}, t_{d}\right], \\
Q(t)=\text { const, } \\
0<v_{d l o} \leq\left(v_{d l o}\right)_{\max }, \\
0<M_{b} \leq\left(M_{b}\right)_{\max },
\end{gathered}
$$

де $M_{b}$ - момент на долоті, $v_{d l o}$ - швидкість спускопідіймальних операцій.

Проблемі вибору оптимального осьового зусилля на долото в разі буріння алмазними долотами РДС приділяється належна увага у вітчизняній і закордонній літературі $[10 ; 11 ; 12 ; 16]$, оскільки технічний оптимум визначає початкову віддаленість об'єкта керування від оптимального режиму відпрацювання долота і впливає на вибір алгоритму функціонування всієї динамічної системи.

Запропоновано $[1 ; 4 ; 10 ; 13 ; 14]$ декілька моделей вибору осьового зусилля на долото. У [10] для визначення інтенсивності зміни осьового зусилля $F(t)$ на долото за глибиною свердловини $h$ використовується модель обмеженого зростання - рівняння Ферхюльста: найбільш важливою ознакою цього рівняння $€$ його нелінійність:

$$
\frac{\mathrm{dF}}{\mathrm{dh}}=a F-b F^{2},
$$

де $a, b$ - відповідно параметри зростання і зменшення осьового зусилля на долото, які визначаються методом найменших квадратів на основі результатів контролю процесу буріння свердловини в режимі on line.

Після заміни проходки $h$ на дискретну змінну $n$ рівняння (8) набуває такого вигляду в рекурентній формі [10]:

$$
F_{n+1}=r F_{n}^{*} \cdot\left(1-F_{n}^{*}\right) ; r=1+a ; F^{*}=d F / r,
$$

де $r$ - параметр, який діагностує режим функціонування динамічної системи.

Дослідження рівняння (12) показує, що множник $\left(1-F_{n}^{*}\right)$ утримує зростання осьового зусилля на долото. Тобто, коли $F_{n}^{*}$ зростає, $\left(1-F_{n}^{*}\right)$ зменшується. Встановлено також [10], якщо $r<1$, то осьове зусилля не доводиться до долота. Якщо $1<r<3$, то забезпечується стійка робота долота. Якщо $r>3$, то можуть виникнути такі технологічні ускладнення, як втрата стійкості бурильної колони, прихват долота й ін. Аналізування показників буріння свердловини № 1 в інтервалі 4 600 $\div 700$ м дозволило встановити [20] значення коефіцієнтів моделі (11) і (12): $a=0,525, b=0,029, r=1,525$. На основі цих даних визначено оптимальне значення осьового зусилля на долото $F=180 \mathrm{kH}$. Збільшення осьового зусилля в цьому інтервалі буріння не привело до підвищення показників буріння, водночас значення діагностуючого коефіцієнта $r$ не перевищувало 2,0 $\div 2,1$.

Основним технічним показником процесу буріння свердловин алмазними долотами $\epsilon$ механічна швидкість $V_{m}$, величина якої впливає на питомі витрати енергії $\omega$, собівартість одного метра свердловини $B$, проходку на долото $h\left(t_{d}\right)$, рейсову швидкість $V_{p}$.

Зауважимо, що точність визначення значення механічної швидкості буріння залежить від числа режимних параметрів і точності їх вимірювання, а також від типу апроксимуючої функції й області апроксимації. Область апроксимації доцільно вибирати в робочому діапазоні зміни параметрів режиму буріння - осьового зусилля $F$ на долото та механічної частоти його обертання $\omega_{b}(t)$, передбаченого геологотехнологічним нарядом.

Визначимо координати базового режиму буріння і вигляд апроксимуючої функції на прикладі критерію оптимізації $w \rightarrow \min$.

Для визначення параметрів $F$ і $\omega_{b}$, що відповідають максимуму механічної швидкості буріння, необхідно взяти часткові похідні від функції $V\left(F, \omega_{b}\right)$ за $F$ i $\omega_{b}$ та прирівняти їх до нуля.

$$
\frac{\partial w\left(F, \omega_{b}\right)}{\partial F}=0, \frac{\partial w\left(F, \omega_{b}\right)}{\partial \omega}=0 .
$$

Урахуємо, що питомі витрати енергії $V$ вимірюються кількістю енергії, яка необхідна для виробництва одиниці продукції, тобто одного метра свердловини:

$$
w=\frac{d W}{d h},
$$

де $W$ - кількість енергії, яка потрібна на поглиблення свердловини на величину $d h$, Дж;

$w$ - питомі витрати енергії, Дж/м. 


\section{АВТОМАТИЗАЦІЯ ТА КОМП'ЮТЕРНО-ІНТЕГРОВАНІ ТЕХНОЛОГІЇ №2ロ 2020}

Оскільки енергія, що підводиться до долота, залежить від осьового зусилля $F$ на долото і частоти обертання $\omega_{b}$, елементарну кількість енергії представимо в такому вигляді:

$$
d W=N \cdot d t=k F \omega_{b} d t
$$

де $N=F \omega_{b}$ - механічна потужність, що витрачається на буріння, Вт;

$d t-$ час, потрібний для збільшення глибини свердловини на $d h$, с;

$k$ - коефіцієнт пропорційності.

Збільшення глибини свердловини залежить від механічної швидкості буріння $V\left(F, \omega_{b}\right)$. Тоді можна записати:

$$
d h=V\left(F, \omega_{b}\right) d t
$$

3 урахуванням формул (14) - (16) вираз для визначення питомих витрат енергії $w$ можна представити в такому вигляді:

$$
w=\frac{k F \cdot \omega_{b}}{V\left(F, \omega_{b}\right)} .
$$

Із (14) можна визначити умови, що забезпечують мінімум питомих витрат енергії:

$$
\frac{\partial \mathrm{V}\left(\mathrm{F}, \omega_{b}\right)}{\partial F}=V F^{-1}, \frac{\partial \mathrm{V}(\mathrm{F}, \omega)}{\partial \omega}=\omega
$$

Із системи рівнянь (18) можна отримати базові значення параметрів режиму буріння $F_{d}$ i $\omega_{d}$, яким відповідає мінімум питомих витрат енергії:

$$
w=\frac{k}{V\left(F, \omega_{b}\right)} F \cdot \omega_{b},
$$

де $\frac{1}{V\left(F, \omega_{b}\right)}=\varepsilon-$ оцінка відносного зношення озброєння долота.

Коли $V\left(F, \omega_{b}\right)=$ const, тоді рівняння (19) можна переписати так:

$$
w=k \cdot F \omega_{b} \cdot \varepsilon .
$$

Оскільки $w=f\left(F, \omega_{b}, \varepsilon\right)$ та $F, \omega_{b}, \varepsilon \in$ неперервними функціями четвертої змінної $t$, то повна похідна дорівнює:

$$
\frac{d w}{d t}=\frac{\partial w}{\partial F} \frac{d F}{d t}+\frac{\partial w}{\partial \omega_{b}} \frac{d \omega_{b}}{d t}+\frac{\partial w}{\partial \varepsilon} \frac{d \varepsilon}{d t} .
$$

Якщо $w$ буде функцією $F$, то формула (21) набуває такого вигляду:

$$
\frac{d w}{d F}=\frac{\partial w}{\partial F}+\frac{\partial w}{\partial \omega_{b}} \frac{d \omega_{b}}{d F}+\frac{\partial w}{\partial \varepsilon} \frac{d \varepsilon}{d F} .
$$

Зазначимо, що часткова похідна $\frac{\partial w}{\partial F}$ складається тільки з однієї складової частини, виходячи з умови, і змінюється лише одна часткова змінна $F$, тоді як $\frac{d w}{d F}=\lim _{\Delta F \rightarrow 0}\left(\frac{\Delta w}{\Delta F}\right)-$ похідна функції $w$ за $F$, що міститься $\mathrm{y} w=f\left(F, \omega_{b}, \varepsilon\right)$ не тільки явно, але ще й неявно, має декілька складових частин, оскільки передбачається, що $\omega_{b}$ i $\varepsilon$ теж деякі функції $F$. Тут $\Delta w$ - повний приріст змінної $w$, викликаний змінами всіх змінних.

Оскільки в разі буріння алмазними долотами 3 постійними режимними параметрами $F=$ const, $\omega_{b}=$ const оцінка відносного зношення озброєння долота $\varepsilon=$ const, то питомі витрати енергії можна розглядати як функцію двох змінних:

$$
w=f\left(F, \omega_{b}\right)
$$

Тоді повна похідна:

$$
\frac{d w}{d t}=\frac{\partial w}{\partial F} \frac{d F}{d t}+\frac{\partial w}{\partial \omega_{b}} \frac{d \omega_{b}}{d t} .
$$

Оскільки $\omega_{b} \epsilon$ функцією $F$, то $w$ в дійсності буде функцією такого вигляду:

$$
\frac{d w}{d F}=\frac{\partial w}{\partial F}+\frac{\partial w}{\partial \omega_{b}} \frac{d \omega_{b}}{d F} .
$$

Помноживши (24) і (21) на $d t$, отримаємо повні диференціали:

$$
\begin{gathered}
\mathrm{dw}=\frac{\partial \mathrm{w}}{\partial \mathrm{F}} d F+\frac{\partial \mathrm{w}}{\partial \omega_{\mathrm{b}}} d \omega_{\mathrm{b}}, \\
\mathrm{dw}=\frac{\partial \mathrm{w}}{\partial \mathrm{F}} d F+\frac{\partial \mathrm{w}}{\partial \omega_{\mathrm{b}}} d \omega_{\mathrm{b}}+\frac{\partial \mathrm{w}}{\partial \varepsilon} d \varepsilon .
\end{gathered}
$$

Рівняння (26) i (27) визначають число dw, яке $\epsilon$ повним диференціалом від питомих витрат енергії, а числа $\frac{\partial \mathrm{w}}{\partial \mathrm{F}} d F, \frac{\partial \mathrm{w}}{\partial \omega_{\mathrm{b}}} d \omega_{\mathrm{b}}, \frac{\partial \mathrm{w}}{\partial \varepsilon} d \varepsilon \epsilon$ частковими диференціалами.

Припустимо, що в рівнянні $(20) \mathrm{k} \cdot \varepsilon=1$, тоді

$$
w=F \cdot \omega_{b} ; \frac{\partial w}{\partial F}=\omega_{b} ; \frac{\partial w}{\partial \omega_{b}}=F .
$$

Підставивши в (24), маємо

$$
\frac{d w}{d t}=\omega_{b} \frac{d F}{d t}+F \frac{d \omega_{b}}{d t} .
$$

Або якщо $\varepsilon \neq 1$, то маємо

$$
\begin{gathered}
w=\frac{k}{V\left(F, \omega_{b}\right)} F \cdot \omega_{b} \quad \frac{\partial w}{\partial \omega_{b}}=\frac{k}{V\left(F, \omega_{b}\right)} F ; \\
\frac{\partial w}{\partial \omega_{b}}=\frac{k}{V\left(F, \omega_{b}\right)} F .
\end{gathered}
$$

Система (30) дозволяє отримати базові значення $F$ i $\omega_{b}$, яким відповідає мінімум питомих витрат енергії $w(x) \underset{x \in S}{\longrightarrow} \min 3$ обмеженнями 


$$
S=\left\{\begin{array}{l}
\left(F_{i}, \omega_{b i}\right)_{i=1 \div n} ; \\
0<F_{\min } \leq F_{i} \leq F_{\max } ; \\
0<\omega_{b_{-} \min } \leq \omega_{b i} \leq \omega_{b_{-} \max } ; \\
\sum_{i=1}^{n} h_{i}=H ; h_{i}>0
\end{array}\right\},
$$

де $\mathrm{H}=$ const - проектна глибина свердловини, яка може бути розділена на $\mathrm{n}$ рівнів, hi - проходка в і-тому рейсі долота.Дійсно, поверхню, що описується рівнянням $w=f\left(F, \omega_{b}\right)$, представимо у тримірному просторі, як це показано на рис. 2.

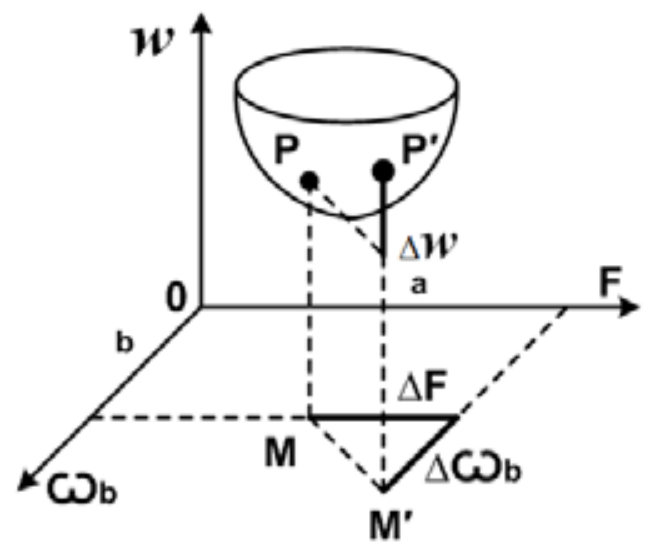

Рис. 2. Поверхня, що описується рівнянням $w=f\left(F, \omega_{b}\right)$

Розглянемо на поверхні постійну точку $P$, для якої $F=a$ і $\omega_{b}=b$. Прирости незалежних змінних $F$ і $\omega$ позначимо $\Delta F$ i $\Delta \omega_{b}$, а питомі витрати енергії $\Delta w$. Тоді $F+\Delta F, \omega_{b+} \Delta \omega_{b}$ i $w+\Delta w$ будуть ординатами точки $P^{\prime}$.

Значення функції $w$ дорівнює $w=f(a, b)=M P$. Отже, функція $f\left(F, \omega_{b}\right)$ двох незалежних змінних $F$ і $\omega_{b}$ неперервна для значення $(a, b)$ змінних $\left(F, \omega_{b}\right)$, оскільки $\lim _{\substack{F \rightarrow a \\ \omega_{b} \rightarrow b}} f\left(F, \omega_{b}\right)=f(a, b)$ незалежно від способу наближення $F$ i $\omega_{b}$ до своїх меж $a$ i $b$.

Якщо в точці $P$ функція неперервна, то незалежно від способу наближення $\Delta F$ і $\Delta \omega_{b}$ до межі, рівної нулю, $\Delta w$ буде також наближатися до межі «нуль», тобто звідки б точка $P^{\prime}$ не наближалася по поверхні до точки $P, M^{\prime} P^{\prime}$ буде завжди прагнути збігтися із $M P$.

Оскільки у функції $w=f\left(F, \omega_{b}\right) F$ і $\omega_{b}$ незалежні, то можна вважати, що $F$ змінюється, але $\omega_{b}$ залишається постійною, і навпаки.

Тоді часткову похідну від $w$ по $F$ за $\omega=$ const можна записати так:

$$
\frac{\partial w}{\partial F}=\lim _{\Delta F \rightarrow 0}\left[\frac{f\left(F+\Delta F, \omega_{b}\right)-f\left(F, \omega_{b}\right)}{\Delta F}\right]=\omega_{b} .
$$

Аналогічно - часткову похідну від $w$ по $\omega$ за $F=$ const можна записати так:

$$
\frac{\partial w}{\partial \omega_{b}}=\lim _{\Delta \omega_{b} \rightarrow 0}\left[\frac{f\left(F, \omega_{b}+\Delta \omega_{b}\right)-f\left(F, \omega_{b}\right)}{\Delta \omega_{b}}\right]=F
$$

Тепер розглянемо рівняння $f\left(F, \omega_{b}\right)=0$, яке визначає або $\Delta F$, або $\Delta \omega_{b}$ як неявну функцію другої змінної. Тут уважаємо, що зміна величини $F$ приводить лише до малої зміни величини $\omega$. Таким рішенням може бути будь-яке рівняння, що містить $\Delta F$ і $\Delta \omega_{b}$, у якому всі члени перенесені в ліву частину.

Нехай $w=f\left(F, \omega_{b}\right)$, отже згідно (25),

$$
\frac{d w}{d F}=\frac{\partial f}{\partial F}+\frac{\partial f}{\partial \omega_{b}} \frac{d \omega_{b}}{d F} .
$$

Проте, враховуючи (29), $f\left(F, \omega_{b}\right)=0$; тобто $w=0$ та $\frac{d w}{d F}=0$.

Отже,

$$
\frac{\partial f}{\partial F}+\frac{\partial f}{\partial \omega_{b}} \frac{d \omega_{b}}{d F}=0 .
$$

Із рівняння (34) маємо

$$
\frac{d \omega_{b}}{d F}=-\frac{\frac{\partial f}{\partial F}}{\frac{\partial f}{\partial \omega_{b}}},\left(\frac{\partial f}{\partial \omega_{b}} \neq 0\right) .
$$

Це формула диференціювання неявної функції. Формула (35) визначає відносні швидкості зміни $\Delta \mathrm{F}$ i $\Delta \omega_{b}$, які утримують $f\left(F, \omega_{b}\right)$ від будь-яких змін. Геометрично це означає, що точка $\left(F, \omega_{b}\right)$ повинна рухатися за кривою, рівнянням якої $є f\left(F, \omega_{b}\right)=0$, а (35) визначає для будь-якого моменту напрямок іiі руху. Із формули (35) бачимо, що зі збільшенням осьового зусилля на долото частота його обертання зменшується.

Саме цей факт $є$ причиною того, що 3 математичного погляду задача встановлення оптимальних параметрів режиму буріння $є$ невизначеною, оскільки в математичних моделях процесу буріння відсутнє ще одне рівняння, яке пов'язує осьове зусилля на долото із частотою його обертання. Для різних способів буріння (роторне, турбобурами, електробурами) ці характеристики приводів подачі й обертання долота суттєво відрізняються.

\section{ВИСНОВКИ}

Проведений аналіз зв'язків керувальних дій у системі автоматизованого управління бурінням свердловин виявив, що відомі математичні моделі процесу поглиблення свердловин як об'єкта керування мають обмежене застосування, оскільки в більшості призначені для шарошкових доліт і не враховують зв'язки між осьовим зусиллям на долото і частотою його обертання.

Запропоновано метод вибору базових значень осьового зусилля на долото і частоти його обертання, який відповідає мінімуму питомих витрат енергії на поглиблення свердловини. 


\section{REFERENCES}

[1] Gorbiychuk, M.I., Sementsov, G.N. (2003). Optimization of the process of drilling deep wells: [textbook. manual]. Ivano-Frankivsk: Torch. 493 p.

[2] Vityaz, O.Yu. Draganchuk, V.I., Vekerik, O.T. (2007). Dynamics of a chisel of cutting type in the course of drilling. IvanoFrankivsk: Torch. 203 p.

[3] Stetyukha, E.I., Golev, A.A/ (1984). Modeling and optimization of the bit processing process. Automation and telemechanization in the oil industry, vol. 2, p.14-19.

[4] Myslyuk, M.A., Zarubin Y.O. (1999). Modeling of phenomena and processes in the oil and gas industry: [textbook. textbook]. Ivano-Frankivsk: Ekor. 496 p.

[5] Kozlovsky, E.A. (1991). Automation of exploration drilling control. M.: Nedra. 215 p.

[6] Brazhnikov, V.A. (1990). Mathematical models of drilling process indicators. Construction of oil and gas wells on land and at sea: EI VNIIOENG, № 8, p. 32-36.

[7] Blizorukov, M.M. Prokopyev, V.P., Sulla, E.O. (1989). Mathematical model of the first approximation of well deepening processes. Sverdlovsk: Institute of Mechanical Engineering of the USSR Academy of Sciences. 29 p.

[8] Rakhimov, A.K., Aizuppe, E.A. (1982). Mathematical support of the operational control system of the drilling process "Uzbekistan-2". Automation and telemechanization of the oil industry, № 2, p. 11-12.

[9] Brevdo, G.D., Brill, G.M., Dmitriev. V.I/ (1981). Operational finding of the optimal drilling mode by the method of stochastic approximation. Automation and telemechanization of the oil industry, № 11, p. 28-36.

[10] Oganov, G.S., Shirin-Zade, S.A., Paramonov, A.A. (2009). Dynamic analysis of the well deepening process. Bulletin of the Association of Drilling Contractors, № 1, p. 40-44.

[11] Parepa, S., Nicolae, I. (2005). Experimental researches regarding the drilling process of the mine shafts by means of surface installations. Annual of the university of mining and geology "St. Ivan Rilski", Vol. 48, Part II, Mining and Mineral processing, pp. 47-52.

[12] Warren, T.M. (1981). Drilling model for soft formation bits. Day. Fri. Tech., June, 33 p.

[13] Eronimi, I.E., Somerton, W.H., Auslander, D.M. (1991). A dynamic model for rotary rock drilling. Trans. ASME, Vol. 104. June, pp. 108-120.

[14] Aboujaoude, C.E. (1991). Modeling, simulation and control of rotary blasthole drills: Master Thesis. Department of Electrical Engineering. MgGill University, Dec. 116 p.

[15] Christoforou, A.P., Yigit, A.S. (1997). Dynamic modeling of rotating drillstrings with borehole interactions. Journal of Sound and Vibration, Vol. 206 (2), pp. 243-260.

[16] Sementsov, G.N., Gutak, O.V. (2014). Modeling and identification of the drilling process for control optimization tasks. Odessa: Kuprienko S.V., 295 p.

\section{СПИСОК ВИКОРИСТАНОЇ ЛІТЕРАТУРИ}

[1] Горбійчук М.І., Семенцов Г.Н. Оптимізація процесу буріння глибоких свердловин : навчальний посібник. ІваноФранківськ : Факел, 2003. 493 с.

[2] Витязь О.Ю. Драганчук В.І., Векерик О.Т. Динаміка долота ріжучого типу в процесі буріння. Івано-Франківськ : Факел, 2007. 203c.

[3] Стетюха Е.И., Голев А.А. Моделирование и оптимизация процесса обработки долота. Автоматизация и телемеханизация в нефтяной промышленности. 1984. Вып. 2. С. 14-19.

[4] Мислюк М.А., Зарубін Ю.О. Моделювання явищ і процесів у нафтогазопромисловій справі : підручник. ІваноФранківськ : Екор, 1999. 496 с.

[5] Козловский Е.А. Автоматизация управления геологоразведочным бурением. Москва : Недра, 1991. 215 с.

[6] Бражников В.А. Математические модели показателей процесса бурения. Строительство нефтяных и газовых скважин на суше и на море. ЭИ ВНИИОЭНГ. 1990. № 8. С. 32-36.

[7] Близоруков М.М., Прокопьев В.П., Сулла Е.О. Математическая модель первого приближения процессов углубления скважин. Свердловск : Институт машиностроения АН СССР, 1989. 29 с.

[8] Рахимов А.К., Айзуппе Э.А. Математическое обеспечение системы оперативного управления процессом бурения «Узбекистан-2». Автоматизация и телемеханизация нефтяной промышленности. 1982. № 2. С. 11-12.

[9] Бревдо Г.Д., Бриль Г.М., Дмитриев В.И. Оперативное нахождение оптимального режима бурения методом стохастической апроксимации. Автоматизация и телемеханизация нефтяной промышленности. 1981. № 11. С. $28-36$.

[10] Оганов Г.С., Ширин-Заде С.А., Парамонов А.А. Динамический анализ процесса углубления скважин. Вестник Асcоичиаиии буровых подрядчиков. 2009. № 1. С. 40-44.

[11] Parepa S., Nicolae I. Experimental researches regarding the drilling process of the mine shafts by means of surface installations. Annual of the university of mining and geology "St. Ivan Rilski”. 2005. Vol. 48. Part II. Mining and Mineral processing. P. $47-52$.

[12] Warren T.M. Drilling model for soft formation bits. Jour. Pet. Tech. 1981. June. 33 p. 
[13] Eronimi I.E., Somerton W.H., Auslander D.M. A dynamic model for rotary rock drilling. Trans. ASME. 1991. June. Vol. 104. P. 108-120.

[14] Aboujaoude C.E. Modelling, simulation and control of rotary blasthole drills: Master Thesis. Department of Electrical Engineering. MgGill University. 1991. Dec. 116 p.

[15] Christoforou A.P., Yigit A.S. Dynamic modelling of rotating drillstrings with borehole interactions. Journal of Sound and Vibration. 1997. Vol. 206 (2). P. 243-260.

[16] Семенцов Г.Н., Гутак О.В. Моделювання та ідентифікація процесу буріння для задач оптимізації управління. Одеса : Куприенко С.В., 2014. 295 с.

(C) В. Б. Кропивницька

Дата надходження статті до редакції: 12.06.2020

Дата затвердження статті до друку: 10.07.2020 